\title{
European Solidarity in Times of Crisis: Comparing Transnational Activism of Civic Organisations in Germany and Greece
}

\author{
Christian Lahusen • Maria Kousis • Ulrike Zschache • Angelos Loukakis
}

(C) The Author(s) 2018. This article is an open access publication.

\begin{abstract}
Civil society organisations have been engaged in solidarity practices in various issue areas, both within their countries and beyond. This paper is interested in analysing whether and to what extent civic initiatives and organisations are involved in transnational solidarity activities within Europe. Moreover, it wishes to identify those factors that seem to promote or inhibit the scope of transnational European activities. The paper compares the situation in two countries (Greece and Germany) on the basis of data on transnationally-oriented civic groups and organisations committed to organising solidarity activities in three fields of work (disabilities, unemployment and immigration of refugees). The analyses show that most solidarity organisations remain active primarily at the local and/or national level/s, and that only a minority of solidarity organisations are engaged in cross-national activities. European activities are associated with organisations maintaining a web of transnational partners and a more politicised mission. Moreover, formalisation and professionalisation seem to be conducive to transnational activism, as much as to global activism. These findings show that cross-national activism can develop at the grass-roots level on the basis of a transnational organisational field that is not nec-
\end{abstract}

C. Lahusen $(\bowtie) \cdot U$. Zschache

Philosophische Fakultät, Universität Siegen, Adolf-Reichwein-Str. 2, 57068 Siegen, Germany

E-Mail: lahusen@soziologie.uni-siegen.de

U. Zschache

E-Mail: zschache@sozialwissenschaften.uni-siegen.de

M. Kousis · A. Loukakis

Department of Sociology, University of Crete, Gallos Campus, 74100 Rethimnon, Kreta, Greece

M. Kousis

E-Mail: kousis.m@uoc.gr

A. Loukakis

E-Mail: loukakisangelos@ social.soc.uoc.gr 
essarily dependent on organisational linkages to the supra- and intergovernmental field of European governance.

Keywords Civil society $\cdot$ Social movement organisations $\cdot$ Solidarity Transnational · European Union · Europe · Horizontal Europeanisation · Greece · Germany

\section{Europäische Solidarität in Zeiten der Krise: ein Vergleich der transnationalen Aktivitäten zivilgesellschaftlicher Organisationen in Deutschland und Griechenland}

Zusammenfassung Organisationen der Zivilgesellschaft haben sich in verschiedenen Problembereichen im Sinne transnationaler Solidarität engagiert. Dieser Beitrag wendet sich diesem Engagement zu und möchte klären, ob und in welchem Umfang bürgerschaftliche Initiativen und Organisationen in transnationalen Solidaritätsaktivitäten involviert sind. Darüber hinaus möchte er diejenigen Faktoren ermitteln, die das Ausmaß transnationaler, europäischer Aktivitäten zu fördern oder zu hemmen scheinen. Die Arbeit verwendet Daten aus einem komparativen Forschungsprojekt, um die Situation in zwei Ländern (Griechenland und Deutschland) und drei Arbeitsbereichen (Behinderungen, Arbeitslosigkeit und Zuwanderung) zu ermitteln und zu vergleichen. Die Ergebnisse zeigen, dass die meisten Solidaritätsorganisationen in erster Linie auf lokaler und/oder nationaler Ebene aktiv sind, weshalb nur eine Minderheit an grenzüberschreitenden Aktivitäten beteiligt ist. Europäische Solidaritätsaktivitäten werden primär von Organisationen getragen, die ein Netz von transnationalen Partnern unterhalten und eine deutlich politische Zielsetzung vertreten. Darüber hinaus scheinen Formalisierung und Professionalisierung dem transnationalen Aktivismus ebenso zuzuarbeiten wie ein globaler Aktionsradius. Diese Ergebnisse zeigen, dass sich transnationale Solidaritätsarbeit auf der Basis eines grenzüberschreitenden Organisationsfeldes entwickeln kann, das nicht notwendigerweise an das supra- und intergouvernementale Feld der Europäischen Union rückgekoppelt ist oder von diesem abhängt.

Schlüsselwörter Zivilgesellschaft · Soziale Bewegungsorganisationen · Solidarität · Transnational · Europäische Union · Europa · Horizontale Europäisierung · Griechenland · Deutschland

\section{Introduction}

The process of European integration has resonated within the field of organised civil society. Citizen initiatives, voluntary associations and protest groups have knitted contacts to similar organisations in other European countries, expanding their missions and their orientation beyond the borders of their nation states, and they have been engaged in mobilising and organising events and campaigns across countries. With the entry of the global financial crisis of 2008, the Eurozone crisis and the refugee crisis of 2015, new citizens' groups and established organisations have 
stepped up the activism in order to support people in need and raise the public awareness necessary for policy measures. In all these facets, we are thus witnessing the development of an organisational field of cross-border solidarity.

Previous research has dealt with these civic organisations by arguing that European integration is encouraging the emergence of a European Civil Society (Smismans 2006; Kutay 2014). Scholars have been interested in the functional role of European civil society within the European system of governance (e.g., Smismans 2003, 2006). They have investigated the pluralism of European civil society with regard to issue fields, representational strategies, modes of action, and national provenience (e.g., Balme and Chabanet 2008; Della Porta and Caiani 2009; Koopmans and Statham 2010). Moreover, they have highlighted the ways in which these organisations react and adapt to accommodative pressures of the EU and insert themselves into the standard operating procedures (Kröger 2008; Ruzza and Bozzini 2008; Kohler-Koch 2010; Kohler-Koch and Quittkat 2013).

Research has thus been interested primarily in the 'vertical Europeanisation' of civil society organisations (Taylor and Mathers 2004; Monforte 2009; KohlerKoch 2010). That is, studies have monitored the extent to which these organisations have reached out to the institutions of the European Union (EU), how they have established organisational structures at the EU level and adapted their activities to EU-related policy domains. The 'scale shift' (Tarrow and McAdam 2005) from the local and national to the European policy arena-as well as their conditions, forms and consequences-were centre stage (Coen 2004; Klüver 2010). Much less is known about 'horizontal Europeanisation', the process by which perceptions, actions and networks of (local or national) civil society actors transcend national borders and reach out to other countries. This transnationalisation has been addressed by social movement analysts (Imig and Tarrow 1999; Eder and Kousis 2001; Della Porta and Caiani 2009), who were interested in the diffusion of local protest events across countries. Findings show that EU-level associations and networks play a role in the coordination of transnational protest activities (Ruzza and Bozzini 2008), but that the 'horizontal Europeanisation' of activism rests mainly on the diffusion and expansion of activities at ground level. Transnational activism thus seems to be a strategic option much more in tune with the grass-roots orientation of many civic groups, and less exposed to the accommodative pressures of the EU-related governance arena (Rucht 2001; Lahusen 2004).

This paper aims to shed light on this area of research by presenting empirical evidence on transnationally-oriented civic groups and organisations that are committed to organising solidarity activities for three target groups, namely people with disabilities, the unemployed and migrants or refugees. Given our interest in 'horizontal Europeanisation', we wish to answer two questions. In descriptive terms, we want to understand the extent to which citizens' groups and organisations in these fields have expanded the scope of their activities into other European countries. In explanatory terms, we wish to compare transnationally-active and inactive organisations in order to identify those organisational characteristics that seem to be associated with transnational solidarity work. For this purpose, we will test a series of research assumptions proposed by previous research that centre on the insertion of these groups into organisational fields across levels (national vs. EU) and 
countries, and on the relevance of organisational features such as the degree of the organisation's formalisation and professionalisation, their action repertoire, and the ideational orientations of these groups.

This paper will make use of a dataset from a cross-national research project ${ }^{1}$ that gathered systematic information on transnationally-oriented citizens' groups and organisations engaged in the field of solidarity, the vast majority of whom are active at the grass-roots level. We will analyse and compare citizens' groups and organisations working in three fields of activity (disability, unemployment, migration/refugees) from two member states (Germany and Greece). The comparative approach will help us to validate whether the organisational profile of transnationally-oriented organised civil society hold true across the three issue fields and two countries under analysis. On first sight, we might expect that differences between civic groups from the two countries and three fields of operation will predominate. Germany and Greece, for instance, represent two countries with structurally diverse civil societies (Kousis 1999; Lyrintzis 2002; Anheier and Salamon 1999; Zimmer et al. 2009). However, the crises affecting the EU, and Greece in particular, have not only led to a considerable growth in Greek organised civil society (Sotiropoulos and Bourikos 2014; Kousis et al. 2016; Simiti 2017), but have also led organisations in both countries to engage more overtly in transnational activities. And while it is to be expected that the three fields of activities have been affected differently by the economic, financial and refugee crises, we cannot overlook that citizens' initiatives and organisations in each of the issue fields have been confronted with crosssectoral grievances and pressures. The comparative design, therefore, will help us to ascertain the similarities and differences between the various groups, as well as the various factors that tend to impinge on the transnational solidarity work of civic groups.

\section{Theorising about transnational solidarity organisations: research concepts and hypotheses}

Studies in social science have paid considerable attention to the activities of citizens' groups and associations within the European Union. Scholars converge on the observation that many of these organisations have expanded the range and scope of their activities beyond their country, and are reaching out to the European Union (Smismans 2006; Ruzza and Bozzini 2008; Kohler-Koch 2010). Even though this debate has been nurtured by different strands of analysis (i.e., the study of organised civil society, of interest groups and of social movements), many scholars have adopted the concept of Europeanisation to describe the process of scale shift and expansion within the organisational fields under study (Imig and Tarrow 1999; Eder and Kousis 2001; Kriesi et al. 2007; Della Porta and Caiani 2007; Roose et al.

\footnotetext{
1 Results presented in this paper have been obtained within the project "European paths to transnational solidarity at times of crisis: Conditions, forms, role models and policy responses" (TransSOL). This project has received funding from the European Union's Horizon 2020 research and innovation programme under grant agreement No 649435. http://transsol.eu/.
} 
2017). By doing so, they borrowed a concept used mainly by analysts interested in public policies and policy-making processes (Featherstone and Raedelli 2003), but adapted it to the new fields of analysis. Within this conceptual framework, the research distinguishes between two processes of Europeanisation. On the one hand, 'vertical Europeanisation' was an area of interest since it implied the creation of a new and supranational area of operation directly linked to EU institutions. The process is related to organisational structures and forms of activism. This implies the establishment of supranational federations, networks or platforms of interest aggregation and representation, above and beyond the field of national and local organisations, the mobilisation and organisation of local and national members, a coordinated 'scale shift' of joint activities, and the insertion of these activities into the institutional arena of EU governance (Taylor and Mathers 2004; Kohler-Koch and Quittkat 2010; Sanchez Salgado 2017). On the other hand, the concept of 'horizontal Europeanisation' was used to grasp the transnationalisation of organisational fields, action repertoires and discourses. In this case, citizens' groups and organisations expand their perceptions, actions and networks across borders into other European countries, without necessarily engaging within the supranational arena of EU politics. This process describes much of what social movement analysts have been analysing, because political protests addressing the EU are more often than not highly decentralised and governed by the dynamics of diffusion, coupling and coordination (Petrova and Tarrow 2007; Tarrow 2011, pp. 191-193; Della Porta and Tarrow 2005).

In this paper, we wish to centre our analysis on the 'horizontal' dimension of Europeanisation, because this aspect has received much less attention within the study of organised civil society, as the latter has been centred primarily on 'vertical Europeanisation' and the study of European associations, networks and platforms. While scholars of social movements have paid attention to the transnational structure of political mobilisation and protest waves, we know very little about whether the wider action repertoires of civil society organisations (e.g., awareness raising, charitable and top-down, as well as bottom-up, solidarity services and initiatives, protest mobilisation) exhibit the same 'horizontal' structures and dynamics. Moreover, our aim is to analyse organisational fields within countries and across different fields of activity, in order to get a more consistent picture of how important 'transnational activism' is at the ground level.

Additionally, we wish to shed more light on the driving and/or constraining forces conditioning this transnationalised activism. Previous studies on civil society have provided ample evidence on the factors influencing vertical Europeanisation. Among others, they have argued that this depends on organisational resources (Coen 2004; Klüver 2010), and the opportunity structure provided by the EU institutions (Marks and McAdam 1996; Eder and Kousis 2001; Sanchez Salgado 2017). But these indications do not necessarily apply to the transnational dimension of civic activism. Hence, we need to take a fresh look at the field of local civil society organisations and extrapolate those organisational factors that seem to facilitate or inhibit cross-national activism. 
Fortunately, we can draw on various strands of research (i.e., the analysis of interest groups, organised civil society and social movements) in order to formulate competing research assumptions that will guide our analysis. In particular, we wish to highlight six hypotheses that will be empirically tested in this paper. First, we need to validate whether 'horizontal Europeanisation' is a function of 'vertical Europeanisation'. In fact, civil society organisations might benefit from engaging in contact with EU institutions and agencies, and/or from membership of European associations and platforms. We know from research that the EU-level allows civil society organisations to get their voice heard across Europe, and thus to exert pressure on national governments (e.g. Della Porta and Caiani 2009, pp. 82-128; Chabanet 2010). At the same time, EU-associations and networks can facilitate access to EU funding opportunities that might help to compensate for the lack of adequate domestic support structures (Kousis 1999; Císař and Vráblíková 2013; Sotiropoulos and Bourikos 2014; Sanchez Salgado 2017). These 'vertical' contacts and memberships might be helpful in expanding the activities of local civil society organisations into other countries, because they facilitate the material resources, contacts and identities needed for this (Ruzza and Bozzini 2008; Sanchez Salgado 2017). On the basis of these arguments, we thus hypothesise that solidarity organisations that maintain contact with the EU and/or belong to European associations will be significantly more active in various countries $\left(\mathrm{H}_{1}\right)$.

Second, we formulate a competing assumption that calls into question the alleged importance of 'vertical Europeanisation'. In fact, it has been shown that European federations and networks encounter problems mobilising the support and commitment of their organisational members at the local level (Petrova and Tarrow 2007; Tarrow 2011, pp. 191-193; Della Porta and Tarrow 2005), and that the lobbying orientation of most Brussels-based Euro-groups alienates them from the more contentious action repertoire at the grass-roots level (Rucht 2001; Lahusen 2004; Balme and Chabanet 2008). Hence, we could postulate that both dimensions of Europeanisation are decoupled, and that horizontal Europeanisation is driven by another rationale. Here, we can refer to studies that have insisted on the importance of direct cooperation between civic groups and social movement organisations from different countries (Bandy and Smith 2005; Tarrow 2011, p. 255, 2005, p. 168). Coalitions might pay off in particular for more informal groups. In fact, although action by the less resourced, informal social movement groups is more limited at the EU level, both formal NGOs and informal SMOs seek to compensate for the low degree of direct actions with a tight network of transnational contacts (Della Porta and Caiani 2007, p. 15). In this sense, we hypothesise that transnationally active solidarity organisations are those reporting about building upon networks of partners in other countries $\left(\mathrm{H}_{2}\right)$.

Third, ideational motivations are taken into consideration by researchers, particularly for those organisations and movements that frame their missions and claims in terms of international solidarity. Civic groups might not only define the issues and conflicts at stake as cross-national problems and contentions, but might also advocate values of internationalism, cosmopolitanism and transnational solidarity (Hunt and Bendford 2004; Ataç et al. 2016). These orientations are an important factor to take into consideration, because we know from research that collective identities and 
shared discourses are crucial for the emergence of collective actions. They allow for building a shared understanding of the problem and a common purpose and mission (Keck and Sikkink 1999; Polletta and Jaspers 2001; Smith 2002). Particularly in a transnational context, we would expect that a discourse devoted to the idea of international or global solidarity will be a necessary correlate of transnational activism. Consequently, we hypothesise that civic groups cheering on transnationalism and cosmopolitanism will be significantly more committed to activities in various countries $\left(\mathrm{H}_{3}\right)$.

Fourth, we need to consider that a 'transnational mission' might not be constrained to Europe, particularly if the vertical insertion of transnational solidarity groups into the supranational field of EU-related agencies, federations and networks is expected to be low. We know from research that social movement organisations and social NGOs have developed transcontinental networks of cooperation and have rallied for a global discourse about solidarity (Keck and Sikkink 1999; Smith et al. 1994; Smith 2002). European solidarity groups that transcend purely local or national activity scopes might thus be attracted much more forcefully to a wider transnational or global field of operation. In this sense, we hypothesise that transnational solidarity work within Europe will be most likely among solidarity groups and organisations with a global scope of action, when compared with local and national initiatives $\left(\mathrm{H}_{4}\right)$.

Fifth, we follow resource mobilisation theory and assume that organisational and human resources are more decisive than shared identities (Edwards and McCarthy 2004). Transnational activism is dependent on these reasons, because it requires more personnel, skills and organisational capacity. At the same time, we expect that organisations with these resources might be more inclined to expand their range of operation beyond their country. Previous studies have shown that formal and professional organisations tend to institutionalise collective action, as they privilege organisational stability and maintenance (Michels 1962; Staggenborg 1988; Minkoff and Powell 2006), and might thus be disposed to reach out to new constituencies and areas of work. Following these lines of reasoning, we expect that formalised and professionalised solidarity organisations will be more prone to reporting about activities within other EU member states, when compared to smaller and less formal groups $\left(\mathrm{H}_{5}\right)$. The former should be able to build on staff, specialised units and organisational capacities, while the latter should be less resourced or willing to invest time and energy beyond their usual area of operation.

Sixth, we assume that action-repertoires might play an important role as well. Organisations might encounter problems when engaging in transnational activism, because their action repertoires (i.e., the type of preferred activities and their strategic orientation) are shaped by local circumstances (e.g., constituencies, policy domains, institutional opportunities). This seems to apply particularly to protest actions. In fact, EU-related protests are more commonly tied to the local level (Imig and Tarrow 2001; Della Porta and Caiani 2007), because they mobilise local constituents, are motivated by local issues, and target national institutions. At the same time, contentious action repertoires might also be held back by domestic contexts because they resonate less with political styles prevalent both at the EU level (Rucht 2001; Lahusen 2004) and within other member states. Hence, we expect that transnation- 
ally-oriented civic groups with a more contentious style of activism will be more focused on local, regional and national levels of action, and thus be underrepresented in the group of those organisations with a transnational scope of activism $\left(\mathrm{H}_{6}\right)$.

In the following, we will empirically assess whether these hypothesised organisational traits hold true across issue fields and countries. We thus abstain from formulating testable hypotheses with regard to these contextual factors, because 'issue fields' and 'countries' are very diffuse variables measuring complex social, historical, cultural and political realities. Regarding these contexts, we propose to formulate two more general propositions. On the one hand, we use the comparative design to validate the proposition that transnational solidarity work is-above all and everywhere - an organisational matter tied to a specific organisational profile. Such a proposition would gain empirical plausibility if organisational traits turn out to be the most relevant factor across all issue fields and countries when transnational solidarity work is at stake. On the other hand, the comparative design will help to identify deviations from this first assumption. In fact, it is highly probable that rates of transnational solidarity work will differ, particularly with regard to countries, given the apparent differences between organisational fields and institutional contexts. Germany, for instance, is marked by a well-established field of civil society organisations (Simonson et al. 2016), a high level of institutionalisation within the public and political domains (Anheier and Salamon 1999; Zimmer et al. 2009), and a high level of insertion into a Europeanised field of civil society activism (Beyers and Kerremans 2007). Greece, contrastingly, is a country with a younger and less institutionalised arena of civil society groups and initiatives (Kousis 1999; Lyrintzis 2002; Clarke et al. 2016) that has grown since the consolidation of its democracy in the seventies, but also after the nineties, due in part to EU funds such as those in the environmental field (Alexandropoulos 2010; Kousis 1999; Eder and Kousis 2001). The economic and financial crises since 2008 and the inflow of refugees during 2015 and 2016 might have led to a gradual convergence between the two countries, due to the gradual increase in civil society groups, contentious and direct solidarity actions in Greece (Sotiropoulos and Bourikos 2014; Diani and Kousis 2014; Kousis et al. 2016; Papadaki and Kalogeraki 2017; Simiti 2017). However, we might expect that differences will persist, thus entailing that national contexts are more important than organisational profiles. In fact, it is plausible to expect that civic groups from Germany will be more strongly represented among the transnationally active when compared to Greece, because the organisational field in Greece is marked by less formal and fewer professionalised groups with an outspoken, contentious approach.

\section{Data and methods}

Our analysis rests on a unique dataset of transnational civic solidarity organisations, using a new, social movements' methodological approach stemming from protest event, protest case and political claims analysis, namely, Action Organisation Analysis (AOA). Data was gathered in the context of a project devoted to the analysis of transnational solidarity, and was carried out in eight European countries (TransSOL 
2016; Kousis et al. 2018). ${ }^{2}$ The main focus was on transnationally-oriented organisations involved in solidarity activities. Data was extracted from randomly chosen organisational websites, following a standardised content analysis based on a crossnationally coordinated and tested codebook.

Mapping organisations and activities online is becoming increasingly important and widespread (Earl and Kimport 2011; Bennett and Segerberg 2012), because it provides research with a new and rich source of data. Organisational websites are not an unfiltered window on reality, because organisations strategically decide what and how to present themselves to a wider audience, e.g., excluding access to sensitive information. However, if the aim is to gather data on the organisation on its own terms, online sources avoid the limitations of mediated sources (e.g. public registers and official reports, or news coverage by conventional mass media) in at least three respects. First, it provides 'unfiltered' information on these organisations by using online directories (hub-websites) usually organised by citizens themselves. These include not only formal but also informal initiatives and organisations, and offer more updated information, compared to other public sources. Second, online sources also allowed us to include more recently established groups, such as migration related organisations which appeared during the refugee crisis of 2015, as well as more informal groups that are not easily located in public directories or on formal lists. Finally, although resource-rich organisations may have more developed websites, our approach, using hubs-based websites, usually created by activists themselves, allowed us to have the best available information on an extensive number of informal and grass-root organisations across the national level that is not usually available from other comprehensive sources used by scholars in the domain (Kousis et al. 2016).

Our data centres on the part of civil society that is explicitly engaged in solidarity work across three specific fields, i.e. with disabled or unemployed people, migrants and refugees within and beyond national borders. The data set consists of the bi-national German and Greek random sample of 600 Transnational Solidarity Organisations (TSOs) - approximately 300 in each country (100 across each of the three fields). This sample does not mirror the organisational field of civil society in its fullness, but focuses on a more delimited section within it, following the overall objective of the research project to analyse 'transnational solidarity groups and organisations'. For this purpose, we have constructed a sample of organisations meeting three criteria of inclusion in terms of their transnational, solidarity and innovation orientation.

First, our aim was to centre on civic groups devoted to solidarity activities on behalf of migrants and refugees, the unemployed and people with disabilities. The organisations are solidarity-oriented in terms of at least one of the following categories: (a) mutual-help, mobilising or collaborating on common interests (bottomup, solidarity exchange), (b) support or assistance between groups, (c) help or offers of support to others and (d) distribution of goods and services to others (top-down, solidarity from above). Second, we were interested in 'innovative' groups insofar as

\footnotetext{
${ }^{2}$ http://transsol.eu/files/2016/12/Integrated-Report-on-Reflective-Forms-of-Transnational-Solidarity. pdf.
} 
their solidarity work responded to actual social challenges, and they were engaged in communication via the Internet. Third, our aim was to map the field of solidarity work with these target groups in its transnational dimension. For this purpose, we opted for an inclusive sampling strategy that is not only interested in civic groups directly engaged in 'transnational solidarity', but also open to all organisations indirectly tied into this field via their partners, supporters or beneficiaries. This sample allows for identifying those factors that distinguish the degree of involvement in transnational solidarity work. From our understanding, organisations are "transnational" if they fall into at least one of the following categories: (a) organisers with at least one organiser from another country, or supranational agency, (b) actions synchronised or coordinated in at least one other country, (c) beneficiaries with at least one beneficiary group from another country, (d) participants/supporters with at least one participating or supporting group from another country, (e) partners/ collaborating groups with at least one from another country, (f) sponsors, with at least one from another country or a supranational agency (e.g. ERDF, ESF), (g) frames with cross-national reference/s, (h) volunteers with at least one volunteer group from another country, and (i) spatial, at least across two countries (at the local, regional or national level). We thus excluded organisations that are: (1) irrelevant to our three fields and devoted to other areas of work (e.g. elderly care, child care), (2) exclusively organised (or led) by the state, the EU, or private corporations, (3) non-solidarity oriented, and (4) with a purely local/national orientation, i.e. without any of the nine transnational features seen above (TransSOL WP2 Integrated Report 2016).

Our unit of observation was the single TSO website ${ }^{3}$, which was systematically extracted from hubs/subhubs, i.e. networks/nodes of similar websites, usually created by citizen activists themselves. The hubs/subhubs ${ }^{4}$, carefully selected by the national teams following a set of common criteria for each field, provided large numbers of website links to social movement and civic organisations that were subsequently retrieved by search engine experts. These nodal-websites were the sources from which the 'population' of civil society, social movement organisations and direct action/solidarity organisations were composed, and from which a random sample of TSOs was drawn, randomised and cleaned using our three criteria of inclusion before coding began.

Based on this mapping approach we identified 10,411 civic and social movement organisations and initiatives for our bi-national data set, 8491 in Germany (Disability: 5513, Migration: 2422, Unemployment: 556) and 1929 in Greece ${ }^{5}$ (Disability: 1079, Migration: 651, Unemployment: 199). The German organisations were extracted through sixteen German hubs/subhubs and more than 1000 additional independent websites. The Greek organisations were extracted from ten Greek hubs/ subhubs, as well as more than 1000 additional independent websites (TransSOL

\footnotetext{
3 When needed and if available on the TSO's website, its social media pages were also used.

4 We also included large numbers of independent websites we located-using keywords-that do not belong to hubs.

5 Excluding a general/humanitarian solidarity hub of 3426 websites which we identified in case there was a need to use it if our 'population' did not provide enough cases meeting our criteria of inclusion.
} 
2016). Using our criteria of inclusion, randomisation and cleaning of our sample followed until each team reached 100 websites per issue field. Following our cleaning procedures with random sets of cases, the number of excluded (non transnational) cases was highest for disability organisations, followed by the unemployment ones. As to migration, sampling was completed quickly since all of the migration organisations met at least one of our criteria of transnationality.

The following empirical analyses make use of the standardised information we extracted from the organisations' websites. In particular, we centre on one core dependent and a series of independent variables. With regard to our dependent variable, we consider civic groups to be 'transnationally active' in the following cases: they reported to be active in at least one other European country as their main area of operation; they affirmed working on behalf of beneficiaries residing in other European countries; and they stated to be engaged in protest action and litigation within Europe or worldwide as supplementary activities. From this group of organisations, we excluded those organisations solely cooperating with EU-level agencies, thus purely Brussels-centred.

In order to empirically validate the theoretical hypotheses introduced before, we operationalised the relevant factors by means of a number of independent variables within our dataset. First, 'vertical Europeanisation' was measured on the basis of two variables that identified organisations having EU or supra-state agencies among their partners, and/or being members of European umbrellas and networks. Second, cross-national networks of cooperation were captured by a variable that listed the number of transnational partners of TSOs. For our purposes, we dichotomised the variable. Third, transnational identities and values were determined on the basis of two variables, one describing the values these organisations are committed to on their websites (in this case, the explicit reference to cross-national or global values of solidarity), and another variable measuring the number of languages on the media outlet. For our analysis, we dichotomised this variable, in order to identify those groups using at least two languages. Fourth, our data assembled information on the spatial scope of operation (e.g., the local, regional, national, European, global). From these multiple answers, we used three additional items (i.e., the local, national and global scopes). Fifth, the relevance of formalisation and professionalisation was measured through two composite variables. Highly formalised organisations were identified as those listing at least seven of the following nine traits: A board, a president or CEO, a secretary or administrative assistant, a treasurer, paid staff, a written constitution, a spokesperson or media representative, a general assembly and specialised committees. Highly professionalised groups were those stating to have at least three out of four professional functions (paid staff, a treasurer, secretary and spokesperson). Finally, we included a number of variables that identify the main action repertoires promoted by these organisations. Reported activities geared at meeting urgent needs (e.g. housing, food, health, clothing) represented the charitable dimension of solidarity work. The political orientation was measured by statements on the websites indicating that policy reforms in at least one area (family/children, poverty, health, disabilities, migration, labour and others) were the organisation's proposed route of action to achieve their aims. Additionally, the use of one of several 
political protest activities (i.e., conventional or demonstrative actions, boycotts or strikes) signalled the contentious orientation of their action repertoires.

The empirical analyses make use of explanatory tools of statistical analysis in order to test the empirical relevance of the various factors described in the previous elaborations. Data analysis, however, has to deal with a small number of cases, particularly with regard to the group of transnationally active TSOs. Consequently, we develop a two-stage strategy of data analysis. In the first step, we ground our analysis on measures of associations (Cramer's V and Fisher's exact) that allow testing the correlation between the few cases of transnational activity of TSOs (dependent variable), and the individual explanatory factors described before for each of the relevant sub-samples in our data. In the second step, we propose to pool the data and analyse an integrated explanatory model that consists only of those factors that have been shown to generate similar effects in both sub-samples. As case numbers are strong enough in this case, the analysis will make use of binary logistic regressions.

\section{Findings}

Our data draw a clear picture of the spatial scope of solidarity activities in Greece and Germany. As shown in Table 1, we see that most TSOs are active at multiple levels, simultaneously. In both countries, the vast majority of TSOs engages within their local environment and still half of them take action at the regional level. This finding is not surprising, given the fact that our online-based strategy of sampling and data retrieval allows for spotting and mapping the field of grass-roots' initiatives in a comprehensive manner. The two countries diverge more clearly when shifting our attention to the other levels of operation. In Greece, half of the TSOs are also active at the national level, while EU and global level activity is of modest relevance. In contrast, German TSOs dedicate similar attention to activities at both the national and EU level. One fifth operates at the national level, and almost as many target the EU level. In addition, a smaller, but still relevant number takes action on a global scale. Hence, German TSOs have a much more Europeanised scope of action than Greek TSOs, in addition to being more globalised than their Greek counterparts.

\subsection{The scope of activities of TSOs: The effect of countries and issue fields}

These findings already show that the national context makes a considerable difference when analysing the transnational activities of civic solidarity groups. In order to validate this impression, we ran statistical tests (Cramer's V and Fisher's exact) that allowed for quantifying the relevance of this factor. Moreover, we added a second group of variables, namely the three issue fields, in order to test whether this context has an effect on transnational activism, too. Table 2 summarises the findings of these tests. While the differences in horizontal activities are significant between countries, the same does not hold true for the issue fields. Organisations working in the field of migration and unemployment are slightly less 'Europeanised' than those groups not working in these areas, and those working in the field of disability 
Table 1 Spatial scope of solidarity activities and supplementary actions (multiple answers, only 'yes')

\begin{tabular}{llllc}
\hline & Germany & \multicolumn{3}{c}{ Greece } \\
Spatial scope of solidarity activities & $N$ & $\%$ & No & $\%$ \\
\hline Local level & 283 & 94.3 & 245 & 58.8 \\
Regional level & 150 & 50.0 & 169 & 47.7 \\
National & 61 & 20.3 & 138 & 9.0 \\
European & 61 & 20.3 & 27 & 4.5 \\
Non-European and global & 36 & 12.0 & 13 & - \\
Total & 300 & - & 297 & \\
\hline
\end{tabular}

Table 2 Transnationally active TSOs across countries and fields

\begin{tabular}{|c|c|c|c|c|c|c|c|c|}
\hline & & \multicolumn{2}{|c|}{ Non-active } & \multicolumn{2}{|c|}{ Active } & \multirow{2}{*}{$\begin{array}{l}\text { Differential } \\
(\%)\end{array}$} & \multirow[t]{2}{*}{ Cramer's V } & \multirow{2}{*}{$\begin{array}{l}\text { Fisher's } \\
\text { exact }\end{array}$} \\
\hline & & $N$ & $\%$ & $N$ & $\%$ & & & \\
\hline \multicolumn{9}{|l|}{ Country (row \%) } \\
\hline Germany & & 239 & 79.7 & 61 & 20.3 & $-11.3 \%$ & $-0.1596 * * *$ & 0.000 \\
\hline Greece & & 263 & 91.0 & 26 & 9.0 & & & \\
\hline \multicolumn{9}{|c|}{ Issue-fields (column \%) } \\
\hline \multirow[t]{2}{*}{ Migration } & Yes & 176 & 34.4 & 23 & 26.1 & $-8.3 \%$ & -0.0624 & 0.142 \\
\hline & No & 335 & 65.6 & 65 & 73.9 & & & \\
\hline \multirow[t]{2}{*}{ Unemployment } & Yes & 172 & 33.7 & 28 & 31.8 & $-1.9 \%$ & -0.0138 & 0.807 \\
\hline & No & 339 & 66.3 & 60 & 68.2 & & & \\
\hline \multirow[t]{2}{*}{ Disabilities } & Yes & 163 & 31.9 & 37 & 42.1 & $10.2 \%$ & 0.0762 & 0.067 \\
\hline & No & 348 & 68.1 & 51 & 57.9 & & & \\
\hline
\end{tabular}

issues are more often active in other European countries. But these differences are not statistically significant. Overall, we see that the horizontal 'Europeanisation' of the organisational fields diverges considerably between countries, but is negligible with regard to issue fields.

Differences between issue fields emerge partially once we disaggregate the data according to the two countries under study. Table 3 shows that issue fields are slightly more relevant when making separate calculations per country. In the field of disabilities, German TSOs are slightly more often engaged in other countries, particularly when compared with Greek groups that tend to refrain more often from these kinds of actions. More significant differences emerge when looking at organisations working in solidarity with migrants and refugees. These organisations are less often transnationally active in Germany, when compared with the pooled data of the two other issue fields, while more Greek groups are active in other countries, even though the coefficient is not statistically significant. This peculiarity seems to mirror the specific situation of 2015, covered by the websites we coded in 2016. Germany experienced the emergence of numerous local initiatives welcoming the incoming refugees, thus privileging a more grass-roots' oriented activism that downplayed transnational activities carried out in other countries. The stronger transnational orientation of the Greek migration/refugees TSOs has been influenced by activities of the larger NGOs whose actions usually include transnational ones, as well as the 
Table 3 Horizontal Europeanisation within issue-fields per country

\begin{tabular}{|c|c|c|c|c|c|c|c|}
\hline & & \multicolumn{2}{|c|}{ Non-active } & \multicolumn{2}{|c|}{ Active } & \multirow[b]{2}{*}{ Cramer's V } & \multirow[b]{2}{*}{$\begin{array}{l}\text { Fisher's } \\
\text { exact }\end{array}$} \\
\hline & & $N$ & $\begin{array}{l}\% \text { Col- } \\
\text { umn }\end{array}$ & $N$ & $\begin{array}{l}\% \\
\text { Column }\end{array}$ & & \\
\hline \multicolumn{8}{|c|}{ German TSOs $(N=300)$} \\
\hline \multirow[t]{2}{*}{ Migration } & No & 148 & (61.9) & 52 & $(85.3)$ & $-0.1991 * * *$ & 0.000 \\
\hline & Yes & 91 & $(38.1)$ & 9 & $(14.7)$ & - & - \\
\hline \multirow[t]{2}{*}{ Disabilities } & No & 169 & $(70.7)$ & 31 & $(50.8)$ & $0.1698 * *$ & 0.006 \\
\hline & Yes & 70 & $(29.3)$ & 30 & $(49.2)$ & - & - \\
\hline \multirow[t]{2}{*}{ Unemployment } & No & 161 & $(67.4)$ & 39 & $(63.9)$ & 0.0293 & 0.649 \\
\hline & Yes & 78 & $(32.6)$ & 22 & $(36.1)$ & - & - \\
\hline \multicolumn{8}{|c|}{ Greek TSOs $(N=299)$} \\
\hline \multirow[t]{2}{*}{ Migration } & No & 187 & $(68.8)$ & 13 & $(48.2)$ & 0.1255 & 0.051 \\
\hline & Yes & 85 & $(31.2)$ & 14 & $(51.8)$ & - & - \\
\hline \multirow[t]{2}{*}{ Disabilities } & No & 179 & $(65.8)$ & 20 & $(74.1)$ & -0.0502 & 0.522 \\
\hline & Yes & 93 & $(34.2)$ & 7 & (25.9) & - & - \\
\hline \multirow[t]{2}{*}{ Unemployment } & No & 178 & $(65.4)$ & 21 & $(77.8)$ & -0.0749 & 0.284 \\
\hline & Yes & 94 & $(34.6)$ & 6 & $(22.2)$ & - & - \\
\hline
\end{tabular}

informal groups who were engaged in transnational protests related to the refugee crisis, such as the 'Open Borders Camp' organised in Thessalonika.

Overall, however, the differences between issue fields are much less prominent and consistent when compared with the divergences between countries. This seems to indicate that the national context is a much more relevant factor to understanding horizontal Europeanisation than issue fields and policy domains.

\subsection{The organisational profile of transnationally active TSOs}

Only a small proportion of Greek and German solidarity groups report to be active in other European countries. In the following, we wish to identify those organisational characteristics that are most relevant when we distinguish between the transnationally active and non-active organisations. Due to the smaller number of cases, we will proceed stepwise and present the findings for each of the individual variables related to our six hypotheses, always comparing results for each of the two countries.

The first two hypotheses aim at validating the importance of organisational linkages and fields. In fact, transnational activities might be a function of 'vertical' and/or 'horizontal' fields of cooperation: i.e., partners at the EU-level and/or within other European countries might provide local solidarity groups with a key to expanding their work beyond their national borders. Table 4 summarises the findings and shows that 'vertical linkages' are not associated with cross-national activities, thus disproving our first hypothesis. In the first instance, we need to note that Greek TSOs report much less frequently about EU-level partners and testify more seldom to being a member in European federations or networks, when compared with German organisations. This relative imbalance corroborates our previous observation that German TSOs are more Europeanised, both in respect to vertical linkages and cross-border activities. However, in both countries there is no statistically signifi- 
Table 4 Vertical and horizontal ties

\begin{tabular}{|c|c|c|c|c|c|c|c|}
\hline & & \multicolumn{2}{|c|}{ Non-active } & \multicolumn{2}{|c|}{ Active } & \multirow[b]{2}{*}{ Cramer's V } & \multirow[b]{2}{*}{$\begin{array}{l}\text { Fisher's } \\
\text { exact }\end{array}$} \\
\hline & & $N$ & $\begin{array}{l}\% \text { Col- } \\
\text { umn }\end{array}$ & $N$ & $\begin{array}{l}\% \text { Col- } \\
\text { umn }\end{array}$ & & \\
\hline \multicolumn{8}{|c|}{ German TSOs $(N=300)$} \\
\hline \multirow{2}{*}{$\begin{array}{l}\text { EU/supra-state } \\
\text { partner }\end{array}$} & No & 172 & $(72.0)$ & 48 & $(78.7)$ & -0.0612 & 0.333 \\
\hline & Yes & 67 & $(28.0)$ & 13 & $(21.3)$ & - & - \\
\hline \multirow{2}{*}{$\begin{array}{l}\text { Member in EU } \\
\text { umbrella }\end{array}$} & No & 208 & $(87.0)$ & 50 & $(82.0)$ & 0.0587 & 0.306 \\
\hline & Yes & 31 & $(13.0)$ & 11 & $(18.0)$ & - & - \\
\hline \multirow{2}{*}{$\begin{array}{l}\text { Transnational } \\
\text { partners }\end{array}$} & No & 100 & $(41.8)$ & 10 & $(16.4)$ & $0.2125 * * *$ & 0.000 \\
\hline & Yes & 139 & $(58.2)$ & 51 & $(83.6)$ & - & - \\
\hline \multicolumn{8}{|c|}{ Greek TSOs $(N=299)$} \\
\hline \multirow{2}{*}{$\begin{array}{l}\text { EU/supra-state } \\
\text { partner }\end{array}$} & No & 249 & $(91.5)$ & 24 & $(88.9)$ & 0.0270 & 0.716 \\
\hline & Yes & 23 & $(8.5)$ & 3 & $(11.1)$ & - & - \\
\hline \multirow{2}{*}{$\begin{array}{l}\text { Member in EU } \\
\text { umbrella }\end{array}$} & No & 263 & $(96.7)$ & 26 & $(96.3)$ & 0.0063 & 1.000 \\
\hline & Yes & 9 & $(3.3)$ & 1 & $(3.7)$ & - & - \\
\hline \multirow{2}{*}{$\begin{array}{l}\text { Transnational } \\
\text { partners }\end{array}$} & No & 165 & $(61.1)$ & 6 & $(22.2)$ & $0.2262 * * *$ & 0.000 \\
\hline & Yes & 105 & $(38.9)$ & 21 & $(77.8)$ & - & - \\
\hline
\end{tabular}

cant relation between both variables, and thus no empirical indication that 'vertical' Europeanisation has had beneficial effects on transnational activism; for Germany, the relation is even slightly negative when considering supra-state and EU-level partners.

With respect to transnational partners, the picture is very different. Cooperation with transnational partners is still more common among German groups than among Greek TSOs; however, the imbalance is much less developed when compared to the other dimensions of transnationalism. In both countries, the two aspects are closely interrelated and statistically significant. That is, TSOs with partners in other countries have a much higher probability of being active across borders than organisations without such partners, thus validating hypothesis two. This finding corroborates the assumption of previous research that networks of cooperation are a crucial resource for civic groups in order to transcend their local area of operation (Kousis 1999; Císař and Vráblíková 2013; Sotiropoulos and Bourikos 2014; Ruzza and Bozzini 2008; Sanchez Salgado 2017). However, additional research into the specific groups named by our TSOs as partners showed that this cooperation is limited to a couple of other European countries. More specifically, German TSOs mention on their websites partners in other European countries, mostly neighbouring ones such as Austria and Switzerland. The Greek TSOs mostly mention partners in the US (usually US-Greek associations), Cyprus and Turkey. It thus appears that the TSOs in both countries choose their partners on the basis of cultural and regional proximity.

A second group of hypotheses aims to check the relevance of organisational identities and missions. A number of TSOs explicitly stated transnational or global values, for instance, the commitment to universal human rights, multiculturalism, international justice or internationalism. Table 5 shows that differences between countries are apparent here, too. German TSOs emphasise their commitment to transnational or global values more often than Greek organisations, once again sub- 
Table 5 Transnational values and global activism

\begin{tabular}{|c|c|c|c|c|c|c|c|}
\hline & & \multicolumn{2}{|c|}{ Non-active } & \multicolumn{2}{|c|}{ Active } & \multirow[b]{2}{*}{ Cramer's V } & \multirow[b]{2}{*}{$\begin{array}{l}\text { Fisher's } \\
\text { exact }\end{array}$} \\
\hline & & $N$ & $\begin{array}{l}\% \text { Col- } \\
\text { umn }\end{array}$ & $N$ & $\begin{array}{l}\% \text { Col- } \\
\text { umn }\end{array}$ & & \\
\hline \multicolumn{8}{|c|}{ German TSOs $(N=300)$} \\
\hline \multirow{2}{*}{$\begin{array}{l}\text { Transnational value } \\
\text { frame }\end{array}$} & No & 114 & $(47.7)$ & 23 & (37.7) & 0.0807 & 0.195 \\
\hline & Yes & 125 & $(52.3)$ & 38 & $(62.3)$ & - & - \\
\hline \multirow{2}{*}{$\begin{array}{l}\text { Media: foreign } \\
\text { language }\end{array}$} & No & 209 & $(87.5)$ & 48 & $(78.7)$ & 0.1006 & 0.100 \\
\hline & Yes & 30 & $(12.5)$ & 13 & $(21.3)$ & - & - \\
\hline \multicolumn{8}{|l|}{ Scope of activities } \\
\hline \multirow[t]{2}{*}{ Local scope } & No & 11 & $(4.6)$ & 6 & $(9.8)$ & -0.0911 & 0.125 \\
\hline & Yes & 228 & $(95.4)$ & 55 & $(90.2)$ & - & - \\
\hline \multirow[t]{2}{*}{ National scope } & No & 205 & $(85.8)$ & 34 & $(55.7)$ & $0.3004 * * *$ & 0.000 \\
\hline & Yes & 34 & $(14.2)$ & 27 & $(44.3)$ & - & - \\
\hline \multirow[t]{2}{*}{ Global scope } & No & 234 & $(97.9)$ & 40 & $(65.6)$ & $0.4626 * * *$ & 0.000 \\
\hline & Yes & 5 & $(2.1)$ & 21 & $(34.4)$ & - & - \\
\hline \multicolumn{8}{|l|}{ Greek TSOs $(N=299)$} \\
\hline \multirow{2}{*}{$\begin{array}{l}\text { Transnational value } \\
\text { frame }\end{array}$} & No & 169 & $(62.1)$ & 10 & $(37.0)$ & $0.1467 *$ & 0.014 \\
\hline & Yes & 103 & (37.9) & 17 & (63.0) & - & - \\
\hline \multirow{2}{*}{$\begin{array}{l}\text { Media: foreign } \\
\text { language }\end{array}$} & No & 199 & $(73.2)$ & 12 & (44.4) & $0.1806^{* *}$ & 0.003 \\
\hline & Yes & 73 & (26.8) & 15 & (55.6) & - & - \\
\hline \multicolumn{8}{|l|}{ Scope of activities } \\
\hline \multirow[t]{2}{*}{ Local scope } & No & 39 & $(14.3)$ & 8 & (29.6) & -0.1204 & 0.050 \\
\hline & Yes & 233 & $(85.7)$ & 19 & (70.4) & - & - \\
\hline \multirow[t]{2}{*}{ National scope } & No & 145 & $(53.3)$ & 8 & (29.6) & $0.1358 *$ & 0.025 \\
\hline & Yes & 127 & $(46.7)$ & 19 & (70.4) & - & - \\
\hline \multirow[t]{2}{*}{ Global scope } & No & 270 & (99.3) & 17 & $(63.0)$ & $0.5301 * * *$ & 0.000 \\
\hline & Yes & 2 & $(0.7)$ & 10 & (37.0) & - & - \\
\hline
\end{tabular}

stantiating that German TSOs have a stronger international focus than Greek TSOs. However, the fact that transnationalism is a more diffused value among German solidarity groups might also be a reason why this factor does not properly discriminate between organisations with and without cross-border activities in this country. Only in the Greek case can we see that transnational and global values are significantly more often associated with horizontal activism, and that this value orientation is much less prominent among transnationally inactive groups.

The picture is inverted when looking at the communication patterns of Greek and German TSOs. While almost one third of all Greek TSOs offer online information in English and other non-native languages, only one out of seven German TSOs does so. It is interesting to note that the majority of transnationally-active German TSOs use only German as their language of communication, thus exhibiting a much more inbound oriented pattern of communication than their counterparts in Greece. For the Greek groups, multilingual communication is a much more diffused correlate of transnational activism. Hence, our third hypothesis is only partly validated for Greece. 
Table 6 Organisational traits and action repertoires

\begin{tabular}{|c|c|c|c|c|c|c|c|}
\hline & & \multicolumn{2}{|c|}{ Non-active } & \multicolumn{2}{|c|}{ Active } & \multirow[b]{2}{*}{ Cramer's V } & \multirow[b]{2}{*}{$\begin{array}{l}\text { Fisher's } \\
\text { exact }\end{array}$} \\
\hline & & $N$ & $\begin{array}{l}\% \text { Col- } \\
\text { umn }\end{array}$ & $N$ & $\begin{array}{l}\% \text { Col- } \\
\text { umn }\end{array}$ & & \\
\hline \multicolumn{8}{|c|}{ German TSOs $(N=300)$} \\
\hline \multirow[t]{2}{*}{ Formalisation } & Low & 204 & $(85.4)$ & 36 & $(59.0)$ & $0.2650^{* * *}$ & 0.000 \\
\hline & High & 35 & $(14.6)$ & 25 & $(41.0)$ & - & - \\
\hline \multirow[t]{2}{*}{ Professionalisation } & Low & 199 & $(83.3)$ & 36 & $(59.0)$ & $0.2369 * * *$ & 0.000 \\
\hline & High & 40 & $(16.7)$ & 25 & $(41.0)$ & - & - \\
\hline \multicolumn{8}{|l|}{ Action repertoire } \\
\hline \multirow[t]{2}{*}{ Urgent needs } & No & 35 & (14.6) & 12 & (19.7) & -0.0557 & 0.329 \\
\hline & Yes & 204 & $(85.4)$ & 49 & $(80.3)$ & - & - \\
\hline \multirow[t]{2}{*}{ Reform oriented } & No & 183 & $(76.6)$ & 23 & $(37.7)$ & $0.3372 * * *$ & 0.000 \\
\hline & Yes & 56 & $(23.4)$ & 38 & $(62.3)$ & - & - \\
\hline \multirow[t]{2}{*}{ Protest activities } & No & 192 & $(80.3)$ & 35 & $(57.4)$ & $0.2153^{* * * *}$ & 0.000 \\
\hline & Yes & 47 & $(19.7)$ & 26 & $(42.6)$ & - & - \\
\hline \multicolumn{8}{|c|}{ Greek TSOs $(N=299)$} \\
\hline \multirow[t]{2}{*}{ Formalisation } & Low & 228 & $(83.8)$ & 20 & $(74.1)$ & 0.0743 & 0.190 \\
\hline & High & 44 & $(16.2)$ & 7 & $(25.9)$ & - & - \\
\hline \multirow[t]{2}{*}{ Professionalisation } & Low & 250 & $(91.9)$ & 24 & (88.9) & 0.0313 & 0.482 \\
\hline & High & 22 & (8.1) & 3 & $(11.1)$ & - & - \\
\hline \multicolumn{8}{|l|}{ Action repertoire } \\
\hline \multirow[t]{2}{*}{ Urgent needs } & No & 67 & $(24.6)$ & 1 & (3.7) & $0.1431^{*}$ & 0.014 \\
\hline & Yes & 205 & $(75.4)$ & 26 & $(96.3)$ & - & - \\
\hline \multirow[t]{2}{*}{ Reform oriented } & No & 221 & $(81.3)$ & 15 & $(55.6)$ & $0.1806^{* *}$ & 0.005 \\
\hline & Yes & 51 & (18.7) & 12 & $(44.4)$ & - & - \\
\hline \multirow[t]{2}{*}{ Protest activities } & No & 121 & $(44.5)$ & 13 & $(48.2)$ & -0.0211 & 0.840 \\
\hline & Yes & 151 & $(55.5)$ & 14 & $(51.8)$ & - & - \\
\hline
\end{tabular}

Not surprisingly, the strongest association between our variables is related to the global scope of activities. However, this finding is not a full confirmation of our fourth hypothesis. In fact, while horizontal activities within Europe are quite diffused among globally-engaged organisations, this does not mean that local or national groups are less committed. On the contrary, when TSOs report that their main area of operation is a local one, they are very often active at the European level, as well. Only in comparative terms can we see a very slight negative correlation between both scopes. This means that European activities are more diffused-in relative terms - among those TSOs with national or global activity scopes. Particularly among the small minority of globally-operating TSOs, activities in various European countries seem to be a firmly established element of their global mission.

Moving to organisational traits and action repertoires, we see in Table 6 that our data illustrate a more mixed picture, emphasising important differences between the countries. Drawing on previous research, we expected that more formalised and professionalised organisations would be more active at the European level. However, this does not seem to be true everywhere, thus confirming our hypothesis only for 
Germany. European activities are more probable among German TSOs with a high degree of formalisation and professionalisation. Here, the effects of a formalised organisational structure are even slightly stronger compared to those of the TSOs' professionalisation.

Nevertheless, it is noteworthy that the level of formalisation and professionalisation is rather low within the overall sample. Solidarity groups and organisations are mainly informal groups of volunteers and activists, and this applies in particular to Greece. These findings show that informal activist groups are as likely to be active at the European level as more formalised and professional organisations. This suggests that professionalisation and formalisation are not necessarily prerequisites for a European mission. The reason behind this observation might be the prominent role of transnational partners, as shown before. Cooperation with other organisations across borders seems to be a highly conducive instrument for European activism, circumventing the need to establish more professionalised and formalised organisational structures. However, it is possible that a stronger formalisation and professionalisation of solidarity groups will boost transnational activities, as in the German case.

Finally, action repertoire and strategic orientations are associated with transnational activism only partially, as shown in Table 6. This is particularly true for the political dimension of solidarity work. In fact, the charitable dimension of TSO activism does not allow for distinguishing clearly between transnationally-active and non-active organisations, simply because this charitable orientation is too strongly diffused across our entire sample. TSOs meeting urgent needs are active at local, national and European levels, alike. In this sense, we must reject our sixth hypothesis in its initial wording. Action repertoires are only a conditioning factor when considering political missions and activities. In fact, TSOs operating in various European countries are more political than those engaged in a more local or national ambit. On their websites, they stress more overtly the need to press for policy reforms as a route to reach their organisational aims. Their political mission might explain their readiness to expand their scope of activities towards other countries, because transnational activism is a widely used strategy among social movement organisations and social NGOs to increase political pressure on governments (Imig and Tarrow 2001; Della Porta and Caiani 2007; Rucht 2001; Lahusen 2004). This interpretation is corroborated by the observation that German TSOs are more active transnationally, in cases where they give stronger emphasis to political protest activities. This finding does not hold true for the Greek case, but once again, the correlation is prevented by the fact that contentious activities are much more diffused throughout the Greek sample, when compared to the German case. Protest mobilisation seems to be as common among solidarity groups operating within the country as it is among organisations reaching beyond borders.

In sum, our findings show that a number of factors confirmed to be relevant in distinguishing between transnationally active and inactive TSOs. Among them, we can name a number of variables that generated statistically significant effects in both countries: Transnational partners $\left(\mathrm{H}_{2}\right)$, a national and global scope of activities $\left(\mathrm{H}_{4}\right)$, and a political commitment to further policy reforms $\left(\mathrm{H}_{6}\right)$. Additionally, we have identified a couple of variables that were not statistically significant in 
Table 7 Transnational activities and their correlates (binary logistic regression)

\begin{tabular}{|c|c|c|c|}
\hline & Model & Model & Model \\
\hline VARIABLES & $\mathrm{a}$ & $\mathrm{b}$ & $\mathrm{c}$ \\
\hline \multicolumn{4}{|l|}{ Vertical/horizontal linkages } \\
\hline Member in European umbrella & 0.111 & -0.156 & -0.228 \\
\hline Transnational partners & $1.478 * * *$ & $0.922 * * *$ & $0.890^{* *}$ \\
\hline \multicolumn{4}{|l|}{ Missions } \\
\hline Transnational/global value frames & - & $0.706^{* *}$ & $0.662^{*}$ \\
\hline Foreign languages of media outlet & - & 0.432 & 0.460 \\
\hline \multicolumn{4}{|l|}{ Scope of activities } \\
\hline Local & - & -0.124 & -0.0689 \\
\hline National & - & $0.600 *$ & 0.182 \\
\hline Global & - & $2.985^{* * *} *$ & $2.901 * * *$ \\
\hline \multicolumn{4}{|l|}{ Organisational traits } \\
\hline Highly formalised & - & - & 0.186 \\
\hline Highly professionalised & - & - & 0.480 \\
\hline \multicolumn{4}{|l|}{ Action repertoires } \\
\hline Policy reform oriented & - & - & $1.123^{* * *}$ \\
\hline Political protest & - & - & -0.0330 \\
\hline \multicolumn{4}{|l|}{ Controls } \\
\hline Issue field: migration & 0.0729 & -0.457 & -0.399 \\
\hline Issue field: disabilities & -0.0103 & -0.186 & -0.156 \\
\hline Issue field: unemployment & - & - & - \\
\hline Country (reference: Germany) & $-0.690^{* * *}$ & $-1.055^{* * *}$ & $-0.738^{*}$ \\
\hline Constant & -1.100 & -1.254 & $-2.369 *$ \\
\hline Observations & 597 & 597 & 597 \\
\hline Pseudo R-squared & 0.0910 & 0.260 & 0.297 \\
\hline
\end{tabular}

Significance levels: $* * * p<0.01, * * p<0.05, * p<0.1$

both countries, but were similarly correlated with transnational activism via positive or negative associations: member in European umbrella, transnational value frame, multilanguage websites, and a local scope of action, professionalisation and formalisation. In order to check for the robustness of these findings, we calculated a binary logistic regression that controlled for issue fields and countries, and introduced the various factors stepwise. Table 7 shows that the overall findings do not diverge considerably from the individual measures of association presented before, even though some variables lose explanatory power.

Overall, only a couple of factors turned out to be relevant within the pooled dataset. These variables tend to converge into a coherent organisational profile. According to these findings, we see that transnationally-active TSOs tend to be slightly more professionalised and formalised. They count on transnational partners and are committed to transnational values, and share a political agenda committed to further policy reforms. While many of them are active at the grass-roots' level, global activism seems to boost transnational activities within Europe significantly. 


\section{Discussion and conclusions}

The various crises currently affecting European citizens have resulted in more solidarity actions beyond borders. In reaction to the financial and economic crisis of 2008 and the more recent migration crisis, citizens' groups and initiatives have mushroomed across Europe. At the same time, established charities, protest groups and voluntary associations have intensified their activism to meet the most urgent needs, raise discontent and address public authorities and policy makers. But how strongly are transnationally-oriented civic groups and organisations active beyond their own borders? And what do we know about those factors inhibiting or promoting a more transnational scope of activity?

So far, little comparative evidence is available on these organisations at the crossnational and cross-fields levels. Research has centred mainly on formalised groups, expanding their range of activities towards the supranational arena, as a scale shift, with specific strategic purposes (Tarrow and McAdam 2005). The aim was to reach out to the new centres of power, from where public policy emanates; to reach out to those institutions that administer new funds and resources that might help to maintain the NGOs' activism; or to reach out towards new arenas of debate, where policy ideas are born and disseminated. According to this strand of research, civil society is internationalising, but in terms of a 'vertical' Europeanisation. Establishing a 'European leg' in Brussels, however, has also meant losing contact with one's own constituencies, and even alienating oneself from grass-roots contacts, due to an inherent process of organisational accommodation within a Brussels' based circuit of insiders, as reported by many studies (Rucht 2001; Lahusen 2004; Balme and Chabanet 2008).

Previous studies have tended to paint a picture of 'vertical Europeanisation' that seems to apply to interest and pressure groups, as well as lobbies and formalised civil society organisations (Smismans 2006; Ruzza and Bozzini 2008; Kohler-Koch 2010; Kutay 2014). The research aim of this paper, though, was a different one, because we were interested in 'horizontal Europeanisation', and thus the expansion of solidarity activities across borders. Our intention was to monitor and map the field of citizen groups and organisations involved in cross-national solidarity. This was possible due to the inclusive methodological approach of our research, geared to map a wide range of transnationally-oriented organisations and groups, provided they communicated their solidarity missions and ventures publicly through their websites. Our findings paint an ambivalent picture of transnational solidarity work. On the one hand, we noted that a large share of civic groups and organisations cherish transnational and global values of solidarity and are in cooperation with partners in other countries. On the other hand, only a small minority of organisations has expanded its own activities beyond borders. Most transnationally-oriented solidarity organisations remain active primarily at the local and/or national level, and tend to limit cooperation with partners to countries in spatial and cultural proximity.

Before this backdrop, we engaged in empirical tests of various hypotheses geared to identify those factors that inhibit or promote transnational activities within Europe. In general terms, we can highlight two main conclusions. In the first instance, our findings show that national contexts matter, given the apparent differences between 
Greek and German TSOs. Greek TSOs are less Europeanised when considering vertical and horizontal linkages (e.g., EU-partners, memberships in European umbrellas, transnational partners), and they are less active in other European countries when compared with German groups. Only with regard to multilingual communication activities are Greek groups more internationally-oriented than German organisations, which seem to be more focused on the German speaking countries. Additionally, Greek organisations are much less formalised and professionalised, and are much more contentious in their action repertoires, thus confirming the findings of previous studies (Lyrintzis 2002; Alexandropoulos 2010; Eder and Kousis 2001; Sotiropoulos and Bourikos 2014; Diani and Kousis 2014; Clarke et al. 2016; Kousis et al. 2016; Simiti 2017). However, differences between countries are primarily related to the level of European commitments and activities, not to the patterns and organisational profiles conditioning 'horizontal Europeanisation'. Moreover, differences between issue fields are negligible.

Before this backdrop, it is noteworthy that our analysis identified a series of organisational characteristics that are significantly related to transnational activities, and that these findings hold true both across countries and issue fields. Our analyses have shown that 'vertical Europeanisation' is not the path leading to the horizontal expansion of activities. It is the cross-border collaboration and cooperation with other groups and organisations that clarifies the European scope of TSOs. In this respect, we see that the field of transnationally-oriented solidarity work shows similar patterns to that in the field of political protests and social movements (Keck and Sikkink 1999; Della Porta and Caiani 2007, p. 15; Tarrow 2005, p. 168, 2011, p. 255). Additionally, our analyses have shown that transnationally active TSOs share a similar organisational profile. 'Horizontal Europeanisation' is more common among organisations that are committed to transnational and global values of solidarity, and stress the importance of political reform. While the vast majority of TSOs consists of informal and less professionalised groups active at the local level, there are some indications proposing that formalisation and professionalisation are conducive to transnational activism, and that global activism seems to be typically associated with cross-border activities within Europe. In this sense, we have to conclude that 'horizontal Europeanisation' seems to be part and parcel of a transnational activism that tends to be spatially smaller and bigger than Europe, when considering that TSOs are active in very specific other European member states and countries outside Europe.

These findings give testimony to an uneven development of transnational solidarity within the field of organised civil society. Civic solidarity with such groups as the jobless, migrants and refugees, or people with disabilities seems to be a highly-decentralised phenomenon, given the prominence of local initiatives and organisations committed to meeting urgent needs and rallying for social rights in their specific area of operation. Only a minority of these groups is engaged in cross-border activities. In this regard, TSOs from countries with a well-developed organisational field, such as Germany, seem to be better equipped to engage in cross-national activism than countries with a less institutionalised and resourced civil society, such as Greece. At the same time, however, we see that 'horizontal Europeanisation' seems to be a path that is more in tune with the grass-roots' orientations, activities and organisational 
forms of TSOs than 'vertical Europeanisation'. In fact, our analyses have shown that cross-national activities are much more common among TSOs with transnational partners, and slightly less common among civic groups and organisations that are oriented towards the supra- and intergovernmental field of EU governance by means of contacts with EU institutions and membership in European associations. The vertical 'scale shift' onto the EU level seems to be an alternative route of action, tentatively discouraging the horizontal expansion of local activities to other countries. This could be an indication that TSOs moving into the arena of EU-governance seem to be confronted with considerable accommodative pressures to adapt their goals, activities and organisations to more conventional arenas of interest representation and policy deliberation (Rucht 2001; Balme and Chabanet 2008; KohlerKoch 2010; Kohler-Koch and Quittkat 2013). Transnational networks of cooperation among national and local TSOs open the door not only to local groups in their ambition to expand their ingrained practices of solidarity with vulnerable groups, but also to those initiatives with a more contentious and advocatory repertoire of actions. In this sense, we might be witnessing the emergence of a limited, albeit notable transnationalised field of European grassroots' solidarity.

Open Access This article is distributed under the terms of the Creative Commons Attribution 4.0 International License (http://creativecommons.org/licenses/by/4.0/), which permits unrestricted use, distribution, and reproduction in any medium, provided you give appropriate credit to the original author(s) and the source, provide a link to the Creative Commons license, and indicate if changes were made.

\section{References}

Alexandropoulos, Stelios. 2010. Collective Action and Interest group Representation before and after 'metapolitefsi' [military junta of 1967-74] in Greece). Athens: Kritiki.

Anheier, Helmut K., and Lester M. Salamon. 1999. Volunteering in cross-national perspective: initial comparisons. Law and Contemporary Problems 62(4):43-66.

Ataç, Ilker, Kim Rygiel, and Maurice Stierl. 2016. Introduction: the contentious politics of refugee and migrant protest and solidarity movements. Remaking citizenship from the margins. Citizenship Studies 20(5):527-544. https://doi.org/10.1080/13621025.2016.1182681.

Balme, Richard, and Didier Chabanet. 2008. European governance and democracy. Power and protest in the EU. Lanham: Rowman \& Littlefield.

Bandy, Joe, and Jackie Smith (eds.). 2005. Coalitions across borders. Transnational protest and the neoliberal order. Lanham: Rowman \& Littlefield.

Bennett, W. Lance, and Alexandra Segerberg. 2012. The logic of connective action. Information, Communication \& Society 15(5):739-768.

Beyers, Jan, and Bart Kerremans. 2007. Critical resource dependencies and the Europeanization of domestic interest groups. Journal of European Public Policy 14(3):460-481. https://doi.org/10.1080/ 13501760701243822 .

Chabanet, Didier. 2010. When the unemployed challenge the European Union: the European marches as a mode of externalization of protest. In The contentious politics of unemployment in Europe. Welfare states and political opportunities, ed. Marco Giugni, 227-243. Houndmills, Basingstoke: Palgrav Mcmillan.

Clarke, Jennifer, Asteris Huliaras, and Dimitri A. Sotiropoulos. 2016. Austerity and the third sector in Greece. Civil society at the European frontline. London: Routledge.

Coen, David. 2004. Environmental and business lobbying alliances in Europe. Learning from Washington? In The business of global environmental governance, ed. David L. Levy, Peter J. Newell, 197-220. Cambridge: MIT Press.

Císař, Ondřej, and Kateřina Vráblíková. 2013. Transnational activism of social movement organizations. The effect of European Union funding on local groups in the Czech Republic. European Union Politics 14(1):140-160. https://doi.org/10.1177/1465116512456311. 
Della Porta, Donatella, and Manuela Caiani. 2009. Social movements and Europeanization. Oxford: Oxford University Press.

Della Porta, Donatella, and Sidney G. Tarrow (eds.). 2005. Transnational Protest and Global Activism. Lanham: Rowman \& Littlefield.

Diani, Mario, and Maria Kousis. 2014. The duality of claims and events. The Greek campaign against the troika's memoranda and austerity, 2010-2012. Mobilization: An International Quarterly 19(4):387-404. https://doi.org/10.17813/maiq.19.4.d865w28177575673.

Earl, Jennifer, and Katrina Kimport. 2011. Digitally enabled social change: activism in the internet age. Cambridge: MIT Press.

Eder, Klaus, and Maria Kousis (eds.). 2001. Environmental politics in Southern Europe. Actors, institutions and discourses in a Europeanizing society. Vol. 29. Dordrecht: Springer.

Edwards, Bob, and John D. McCarthy. 2004. Resources and social movement mobilization. In The Blackwell companion to social movements, ed. David A. Snow, Sarah A. Soule, and Hanspeter Kriesi, 116-152. Malden: Blackwell.

Featherstone, Kevin, and Claudio M. Radaelli (eds.). 2003. The politics of Europeanization. Oxford: Oxford University Press.

Hunt, Scott A., and Robert D. Benford. 2004. Collective identity, solidarity, and commitment. In The Blackwell companion to social movements, ed. David A. Snow, Sarah A. Soule, and Hanspeter Kriesi, 433-457. Malden: Blackwell Publishing.

Imig, Doug, and Sidney Tarrow. 1999. The Europeanization of movements? A new approach to transnational contention. In Social movements in a globalizing world, ed. Donatella della Porta, Hanspeter Kriesi, and Dieter Rucht, 112-133. Basingstoke: Palgrave Macmillan.

Imig, Doug, and Sidney G. Tarrow. 2001. Contentious Europeans. Protest and politics in an emerging polity. Lanham: Rowman \& Littlefield.

Keck, Margaret E., and Kathryn Sikkink. 1999. Transnational advocacy networks in international and regional politics. International Social Science Journal 51(159):89-101. https://doi.org/10.1111/14682451.00179.

Klüver, Heike. 2010. Europeanization of lobbying activities. When national interest groups spill over to the European level. Journal of European Integration 32(2):175-191. https://doi.org/10.1080/ 07036330903486037.

Kohler-Koch, Beate. 2010. Civil society and EU democracy. 'Astroturf' representation? Journal of European Public Policy 17(1):100-116. https://doi.org/10.1080/13501760903464986.

Kohler-Koch, Beate, and Christine Quittkat. 2013. De-mystification of participatory democracy. EU-governance and civil society. Oxford: Oxford University Press.

Koopmans, Ruud, and Paul Statham (eds.). 2010. The making of a European public sphere. Media discourse and political contention. Cambridge: Cambridge University Press.

Kousis, Maria. 1999. Sustaining local environmental mobilisations. Groups, actions and claims in Southern Europe. Environmental politics 8(1):172-198. https://doi.org/10.1080/09644019908414443.

Kousis, Maria, Stefania Kalogeraki, Marina Papadaki, Angelos Loukakis, and Maria Velonaki. 2016. Alternative Formen von Resilienz in Griechenland. Forschungsjournal neue soziale Bewegungen 29:50-61. https://doi.org/10.1515/fjsb-2016-0108.

Kousis, Maria, Marco Giugni, and Christian Lahusen. 2018. Action organization analysis: Extending protest event analysis using websites. American Behavioral Scientist, forthcoming.

Kriesi, Hanspeter, Anke Tresch, and Margit Jochum. 2007. Going public in the European Union. Action repertoires of Western European collective political actors. Comparative Political Studies 40(1):48-73. https://doi.org/10.1177/0010414005285753.

Kröger, Sandra. 2008. Nothing but consultation. The place of organised civil society in EU policy-making across policies. European Governance Papers, Nr. C-08-03. https://EconPapers.repec.org/RePEc:erp: eurogo:p0019. Accessed 9 Jan 2018.

Kutay, Acar. 2014. Governance and European Civil Society. Governmentality, discourse and NGOs. London: Routledge.

Lahusen, Christian. 2004. Joining the cocktail-circuit. Social movement organizations at the European Union. Mobilization: An International Quarterly 9(1):55-71. https://doi.org/10.17813/maiq.9.1. 106w4m11367600w4.

Lyrintzis, Christos. 2002. Greek civil society in the 21st century. In Greece in the European Union. The new role and the new agenda, ed. Panayotis C. Ioakimidis, 90-99. Athens: Ministry of Press and Mass Media. 
Marks, Gary, and Doug McAdam. 1996. Social movements and the changing structure of political opportunity in the European Union. West European Politics 19(2):249-278. https://doi.org/10.1080/ 01402389608425133.

Michels, Robert. 1962. Political parties. A sociological study of the oligarchical tendencies of modern democracy. New York: Free Press.

Minkoff, Debra C., and Walter W. Powell. 2006. Nonprofit mission: constancy, responsiveness, or deflection? In The nonprofit sector. A research handbook, 2nd edn., ed. Walter W. Powell, Richard Steinberg, 591-611. New Haven: Yale University Press.

Monforte, Pierre. 2009. Social movements and Europeanization processes. The case of the French associations mobilizing around the asylum issue. Social Movement Studies 8(4):409-425. https://doi.org/ 10.1080/14742830903234288.

Papadaki, Marina, and Stefania Kalogeraki. 2017. Social support actions as forms of building community resilience at the onset of the crisis in urban Greece. The case of Chania. Partecipazione e Conflitto 10(1):193-220. https://doi.org/10.1285/i20356609v10i1p193.

Petrova, Tsveta, and Sidney Tarrow. 2007. Transactional and participatory activism in the emerging European polity. The puzzle of East Central Europe. Comparative Political Studies 40(1):74-94. https:// doi.org/10.1177/0010414006291189.

Polletta, Francesca, and James M. Jasper. 2001. Collective identity and social movements. Annual review of Sociology 1(27):283-305. https://doi.org/10.1146/annurev.soc.27.1.283.

Porta, Della Donatella, and Manuela Caiani. 2007. Europeanization from below? Social movements and Europe. Mobilization: An International Quarterly 12(1):1-20. https://doi.org/10.17813/maiq.12.1. j48p252t414qu05x.

Roose, Jochen, Kostas Kanellopoulos, and Moritz Sommer. 2017. National anti-austerity protests in a European crisis. Comparing the Europeanizing impact of protest in Greece and Germany during the Eurozone crisis. Journal of Civil Society 13(3):284-306. https://doi.org/10.1080/17448689.2017. 1362137.

Rucht, Dieter. 2001. Lobbying or protest? Strategies to influence EU environmental policies. In Contentious Europeans: protest and politics in an emerging polity, ed. Doug Imig, Sidney Tarrow, 125-161. Lanham: Rowman \& Littlefield.

Ruzza, Carlo, and Emanuela Bozzini. 2008. Organised civil society and European governance. Routes of contestation. European Political Science 7(3):296-303. https://doi.org/10.1057/eps.2008.25.

Sanchez Salgado, Rosa. 2017. Europeanization of civil society organizations in times of crisis? Exploring the evolution grant-seeking strategies in the EU multi-level system. European Politics and Society 18(4):511-528. https://doi.org/10.1080/23745118.2017.1286283.

Simiti, Marilena. 2017. Civil society and the economy. Greek civil society during the economic crisis. Journal of Civil Society 13(4):357-373. https://doi.org/10.1080/17448689.2017.1355033.

Simonson, Julia, Claudia Vogel, and Clemens Tesch-Römer (eds.). 2016. Freiwilliges Engagement in Deutschland, Der Deutsche Freiwilligensurvey 2014. Wiesbaden: Springer VS.

Smismans, Stijn. 2003. European civil society. Shaped by discourses and institutional interests. European Law Journal 9(4):473-495. https://doi.org/10.1111/1468-0386.00187.

Smismans, Stijn. 2006. Civil society and legitimate European governance. Cheltenham: Edward Elgar.

Smith, Jackie. 2002. Bridging global divides? Strategic framing and solidarity in transnational social movement organizations. International Sociology 17(4):505-528. https://doi.org/10.1177/ 0268580902017004003.

Smith, Jackie, Ron Pagnucco, and Winnie Romeril. 1994. Transnational social movement organisations in the global political arena. Voluntas: International Journal of Voluntary and Nonprofit Organizations 5(2):121-154. https://doi.org/10.1007/BF02353983.

Sotiropoulos, Dimitri A., and Dimitris Bourikos. 2014. Economic crisis, social solidarity and the voluntary sector in Greece. Journal of Power, Politics \& Governance 2(2):33-53.

Staggenborg, Suzanne. 1988. The consequences of professionalization and formalization in the pro-choice movement. American Sociological Review 53(4):585-605. https://doi.org/10.2307/2095851.

Tarrow, Sidney. 2005. The new transnational activism. Cambridge: Cambridge University Press.

Tarrow, Sidney. 2011. Power in movement. Social movements and contentious politics. Cambridge: Cambridge University Press.

Tarrow, Sidney, and Doug McAdam. 2005. Scale shift in transnational contention. In Transnational protest and global activism, ed. Donatella Della Porta, Sidney Tarrow, 121-150. Lanham: Rowman \& Littlefield. 
Taylor, Graham, and Andrew Mathers. 2004. The European Trade Union confederation at the crossroads of change? Traversing the variable geometry of European Trade Unionism. European Journal of Industrial Relations 10(3):267-285. https://doi.org/10.1177/0959680104047021.

TransSOL. 2016. Integrated Report on Reflective Forms of Transnational Solidarity. Online accessible via: transsol.eu/files/2016/12/Integrated-Report-on-Reflective-Forms-of-Transnational-Solidarity.pdf

Zimmer, Annette, Anja Appel, Claudia Dittrich, Birgit Sittermann, and Freja Stallmann. 2009. Germany: On the Social Policy Centrality of the Free Welfare Associations. In Handbook on Third Sector Policy in Europe. Multi-level Processes and Organized Civil Society, ed. Jeremy Kendall, 21-42. Cheltenham: Edward Elgar.

Christian Lahusen holds a Chair of Sociology at the Faculty of Arts at Siegen University.

Maria Kousis $\mathrm{PhD}$, University of Michigan, 1984, is Professor of Sociology and Director of the Centre for Research and Studies at the University of Crete.

Ulrike Zschache is a Post-Doctoral Research Assistant at the Department of Social Sciences of the Siegen University.

Angelos Loukakis is PhD Candidate in Sociology and Researcher at the Centre for Research and Studies at the University of Crete. 